\title{
Groundwater Chemical Evolution in the Essaouira Aquifer Basin-NW Morocco
}

\author{
Mohammed Bahir ${ }^{1}$, Rachid El Moukhayar ${ }^{1}$, Najiba Chkir ${ }^{2}$, Hamid Chamchati ${ }^{1}$, \\ Paula Galego Fernandes ${ }^{3}$, Paula Carreira ${ }^{3}$ \\ ${ }^{1}$ Geodynamics Laboratory Magmatic Géoressources and Georisks, Université Cadi Ayyad, Marrakech, Morocco; ${ }^{2}$ Geography De- \\ partement, Faculty of Letters and Humanities, Sfax University, Sfax, Tunisia; ${ }^{3}$ Nuclear Technology Institute, Sacavém, Portugal. \\ Email: bahir@ucam.ac.ma
}

Received September $19^{\text {th }}, 2012$; revised October $20^{\text {th }}, 2012$; accepted October $28^{\text {th }}, 2012$

Copyright (C) 2013 Mohammed Bahir et al. This is an open access article distributed under the Creative Commons Attribution License, which permits unrestricted use, distribution, and reproduction in any medium, provided the original work is properly cited.

\begin{abstract}
The sustainability of groundwater resources for drinking water supplies, agriculture, and industry a prime concern in countries dominated by arid and semi-arid climates such as Morocco. The growing demand for groundwater coupled with impacts from land use and climate change make sustainability an even more important water management goal. In order to make sound decisions about water use and protection of water quality, managers and policy makers must have a sound understanding of such factors as the location and amount of groundwater recharge and groundwater ages. Due to the population growth and climate change (causing long periods of drought) in the world, many countries have intensively increased their use of water sources for supplying potable water to population and for their agricultural (irrigation) and industrial developments. Due to the lack of surface waters, people exploit mainly underground water reservoirs. So, it is necessary to study and characterize these water reservoirs to avoid any excess of exploitation. The water resources of the Essaouira basin are characteristic of a semi-arid climate, and are severely impacted by the climate (quantity and quality). Considering the importance of the Essaouira aquifer in the groundwater supply of the region, a study was conducted in order to comprehend this aquifer groundwater evolution. It is an aquifer located on the Atlantic coastline, southern (Morocco), corresponding to a sedimentary basin with an area of near $200 \mathrm{~km}^{2}$. Covering the Palaeozoic bedrock, the sedimentary series range from the Triassic to the Quaternary. The geological structures delineate a syncline bordered by the Tidzi diapir of Triassic age which outcrops to the East and South. In the Essaouira basin a multi-aquifer was identified constituted by detrital deposits of the Plioquaternary and dolomitic limestones of the Turonian. The Plioquaternary is unconfined below the Senonian marls. However, in some places it can be in direct contact with the other Cretaceous and Triassic units. The Plioquaternary is generally up to $60 \mathrm{~m}$ thick. The Turonian is confined by the Senonian marls and in direct contact with the Plioquaternary on the edges of the syncline structure. The main flow direction is from SE to NW towards the Atlantic Ocean, being the recharge area located near the Tidzi diapir. In the Essouaira basin, in spite of the occurrence of calcareous and dolomitic levels, all waters are of Na-Cl-type. The chemical signature of these waters should be the result of the preferential recharge area that is located in the Tidzi diapir. Using a simple mass balance model through the PHREEQC program this scenario was tested. The reaction path was assumed to be such that waters observed at shallow depths evolved to more mineralized waters. It was possible to notice that these waters have an important contribution of water-rock interaction in groundwater mineralization, corroborating the influence of the preferential recharge area located in the Tidzi diaper in the waters signature.
\end{abstract}

Keywords: Essaouira Basin Aquifer; Hydrogeochemistry; Mass Balance Model

\section{Introduction}

Morocco is characterized by a semi-arid to arid climate, excluding a humid zone in the north. This climat constraint requires the application of new technologie to supplement conventional hydrological method, in order to improve water resources assessment and management in Morocco.

In coastal regions, the problems related with the increase of salinization and pollution in groundwater systems is generally associated to the effects of seawater (seawater intrusion by overexploitation of the system and by sea-salt-spray) and on the other hand by the anthropogenic activities such as domestic wastes, agriculture 
and industry. Also, intrinsic properties of aquifers (porous/fractured/karstic media, geological structure, permeability), and external factors such as climate may contribute to mitigate or worsen these problems.

The Essaouira basin is located in a Moroccan semiarid area with maximum annual rainfall of $300 \mathrm{~mm} /$ year and with a high potential evapotranspiration around 920 $\mathrm{mm} /$ year [1,2] (Figure 1).

This sedimentary basin has an area of about $1200 \mathrm{~km}^{2}$ and is filled with Mesozoic and Cenozoic materials, which are overlaid with superficial Plioquaternary terrains (Figure 2). One main aquifer was identified, supplying water for drinking and for agricultural activities [3].

\section{Geological and Hydrogeological Data}

Covering the Palaeozoic bedrock, the sedimentary series range from the Triassic to the Quaternary. The sedimentary sequence begins with Triassic deposits having the same lithology as in Sines basin, outcroping in the E and $\mathrm{S}$ of the region. The Carbonate rocks compose the Jurassic and marly sediments of lower Cretaceous to Cenomanian dominate the Cretaceous. The dolomitic limestones of the Turonian are covered by Senonian gypsy marls $[4,5]$, which appear below the Plioquaternary detrital deposits of sands, sandstone and conglomerates. The geological structures delineate a syncline bordered by the Tidzi diapir of Triassic age which outcrops to the E and S.
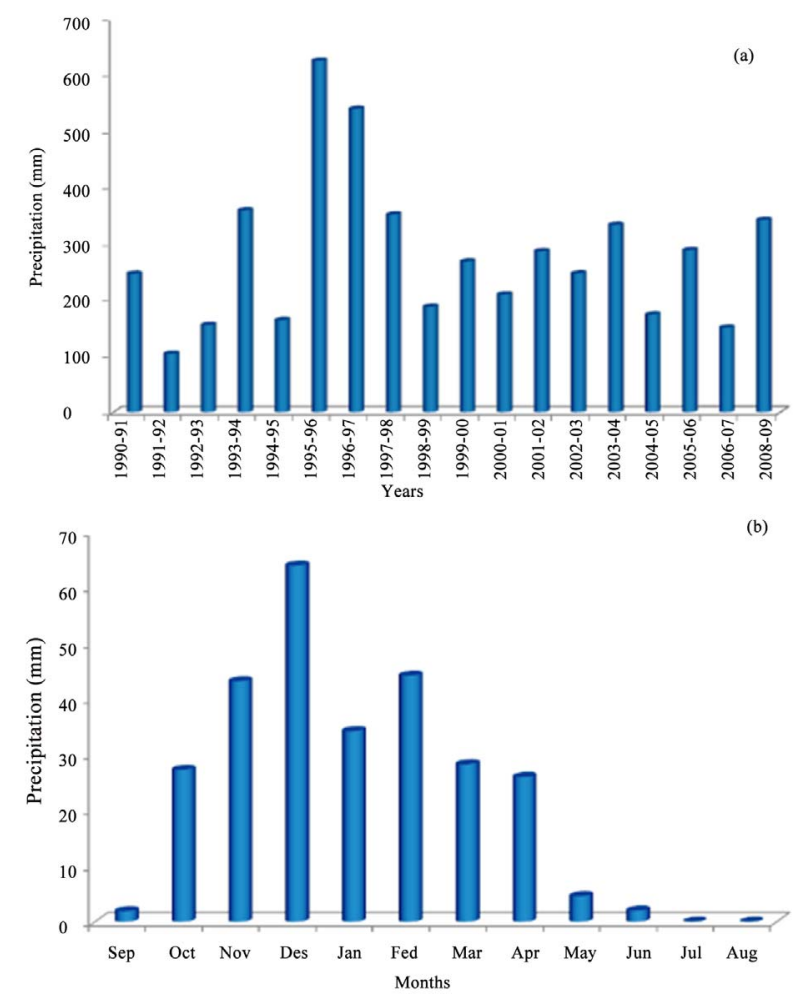

Figure 1. Precipitation (a) annual values and (b) monthly mean values at Essaouira Station (1990-1991 to 2008-2009).

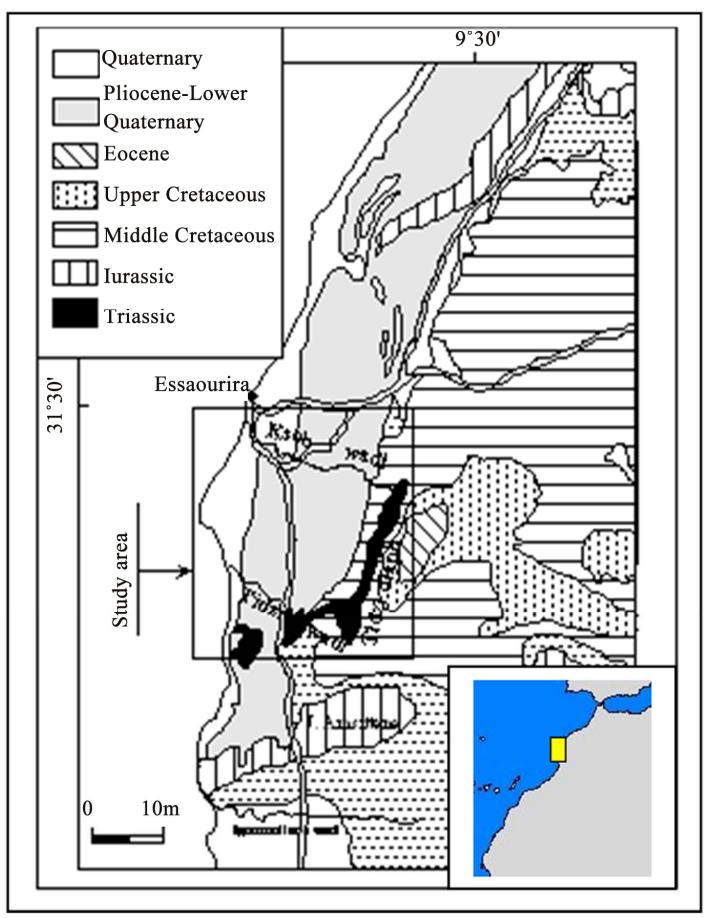

Figure 2. Geological map of essaouira basin.

In the Essaouira basin a multi-aquifer was identified constituted by detrital deposits of the Plioquaternary and dolomitic limestones of the Turonian [6].

The Plioquaternary is unconfined below the Senonian marls. However, in some places it can be in direct contact with the other Cretaceous and Triassic units. The Plioquaternary is generally up to $60 \mathrm{~m}$ thick.

The Turonian is confined by the Senonian marls and in direct contact with the Plioquaternary on the edges of the syncline structure.

For a few years, water has been withdrawn through drilling wells to supply the Essaouira City. At present, the Plioquaternary provides $47 \%$ of drinking water for Essaouira with about 64,000 inhabitants and rural population. The total rate of extraction in this system is around $97 \mathrm{~L} / \mathrm{s}$ [7].

The piezometric levels in the Essaouira multi-aquifer present a general standardization through time (1990/ 2000). However, locally some piezometric variations can be identified. As a consequence of the weak thickness the sensibility to the droughts have an important impact in the water reservoir, as widespread drought periods that are affecting Morocco since 1978 [7].

Morocco has a wide range of climate conditions: the coastal regions generally have a mild climate, the Atlas Mountains can be cold and wet during spring or even in summer, while the desert is hot and dry nearly all year.

The main flow direction is from SE to NW towards the Atlantic Ocean, being the recharge area located near the Tidzi diaper. The piezometric maps, since 1990 to 2000, 
show, in the $\mathrm{N}$, a line deviation to the NE, indicating a possible contribution of the oued in the aquifer recharge.

In the Essouaira basin, in spite of the occurrence of calcareous and dolomitic levels, all waters are of $\mathrm{Na}-\mathrm{Cl}-$ type (Table 1 and Figure 3).

The diagram allows not only representation of the hydrochemical data, but also definition of the plausible hydrochemical processes dominating the groundwater chemistry such as mixing, ion exchange and dissolution affecting groundwater composition. Classification of water into "types" according to the dominating cations and anions can then be undertaken.

The chemical signature of these waters should be the result of the preferential recharge area that is located in the Tidzi diapir. A high correlation coefficient was found between electrical conductivity, chlorides and sodium contents, suggesting the large contribution of these elements to the groundwater chemical load. Nevertheless, occulted by chloride the groundwater is highly bicarbonate as a result of the presence of carbonate compounds in the reservoirs matrix.

Analyzing the dispersion of the values of the parameters, it is probable that the difference between the maximum values and the average is a result of a punctual increase. However, the present range is in majority a result of the oued contribution into groundwater recharge, leading to a dilution of the water mineralization. Another hypothesis to explain the range in mineralization could be the available time in the water rock interaction with the diapir that constitutes the basin. It is also important to consider the huge concentrations in chloride and sodium (5019 and $3133 \mathrm{mg} / \mathrm{L}$ ), not included in the diagram because of the anomaly behaviour of the well number 45 located near the coastline on the NW of the area. These values could be a result of a local intrusion phenomena originated by over exploitation.

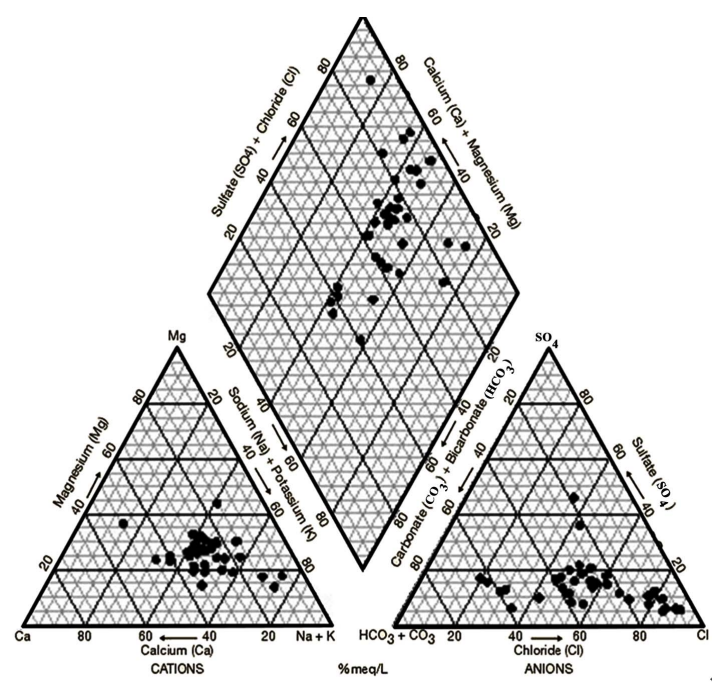

Figure 3. Essaouira groundwater piper diagram.
On the basis of Durov diagram (Figure 4), the water within the aquifer of the Essaouira basin can be considered as mostly homogeneous, among which sodium and chloride are the most dominant facies. These waters types can be described as follows: waters for the two aquifers are plotted in the box 9 indicating increasing salinity by mixing processes and in box 8 highlighting the existence of cation reverse exchange reactions within the Turonian as well as within the Plio-Qaternary aquifers.

\section{Groundwater Geochemical Characterization}

Hydrogeochemical processes are important in defining groundwater hydrology in complex layered aquifers. Subtle variations of salinity in fresh groundwaters are related to hydrogeochemical processes controlling groundwater composition. Three physical parameters $(\mathrm{T}, \mathrm{pH}$,

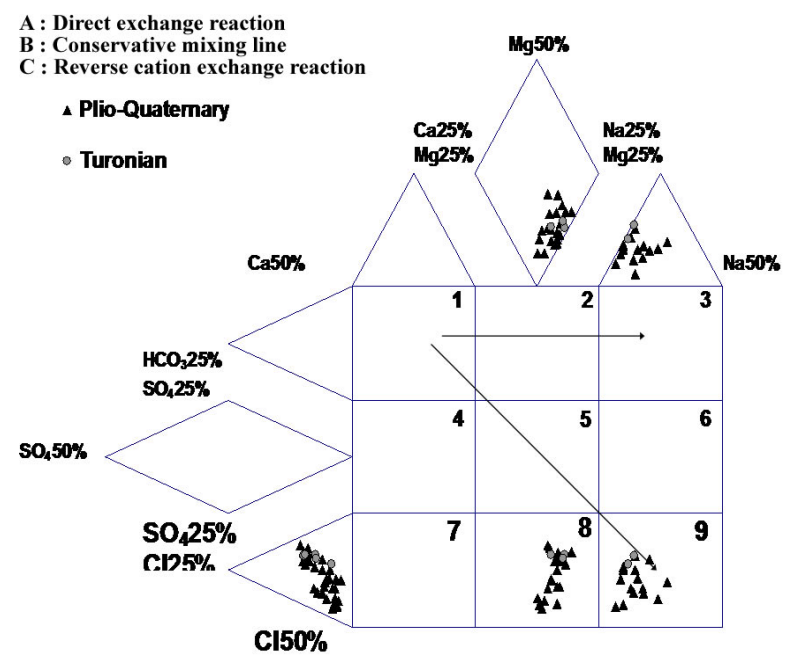

Figure 4. Expanded durov diagram for the essaouira groundwater.

Table 1. Factorial analyses in the essaouira basin.

\begin{tabular}{cccc}
\hline & Factor 1 & Factor 2 & Factor 3 \\
\hline $\mathrm{HCO}_{3}^{-}$ & -0.05209 & 0.56697 & -0.59120 \\
$\mathrm{Cl}^{-}$ & 0.91966 & -0.24626 & 0.20629 \\
$\mathrm{NO}_{3}^{-}$ & 0.51705 & -0.59032 & 0.05719 \\
$\mathrm{SO}_{4}^{2-}$ & 0.10906 & 0.82363 & 0.23708 \\
$\mathrm{Na}^{+}$ & 0.83928 & 0.23035 & 0.16783 \\
$\mathrm{~K}^{+}$ & 0.03055 & 0.24041 & 0.85555 \\
$\mathrm{Ca}^{2+}$ & 0.82401 & -0.14683 & -0.02267 \\
$\mathrm{Mg}^{2+}$ & 0.83775 & 0.09662 & -0.43083 \\
\hline
\end{tabular}


conductivity) have been measured in situ during sampling with a handling multiparameters equipment. Chemical analysis have been realised according to standard protocols in the Laboratory of 3 Geolab of University Cadi Ayyad of Marrakech.

Unfortunately, levels of physical-chemical parameters such as TDS, EC, $\mathrm{Cl}^{-}, \mathrm{SO}_{4}^{2-}$ are higher than the maximum permissible level prescribed by the World Health Organization standards sets fro drinking water.

\subsection{Principal Component Analysis}

Considering the numerous species involved in the chemical analyses, the sources of salinization were sought using Principal Component Analysis (PCA). PCA is a Factorial Analysis, in which graphs are generalised, taking into account all the elements involved, in order to achieve optimal data visualization [8]. Using this statistical analysis a reduction of the observation dimensions species obtained in which the given objects are studied, by creating linear combinations of variables that characterize the studied objects [9].

The application of the PCA method to Essaouira groundwater data allows the identification of 3 factors with eigen values greater than 1 (Tables 1 and 2):

Factor 1 represents $41 \%$ to the total variance of the groundwater system with a positive correlation between chloride, sodium, calcium and magnesium. This pattern materialises the water-rock interaction namely the dissolution of evaporate minerals and/or the contribution of Tidzi diapir in the water recharge.

Factor 2 with a relevance of $19 \%$ to the groundwater characterization represents the sulphates content. These values could have natural or anthropogenic origins, resulting from evaporatic dissolution and/or the use of fertilisers.

Factor 3 represents $17 \%$ of the total variance and it is probably the result of the influence of the bedrock in the water mineralization; factor 3 shows a high correlation with potassium.

The samples recovered after the exceptional rainfalls in January 1996, show a remarkable increase in $\mathrm{Na}^{+}$and $\mathrm{Cl}^{-}$concentrations when compared with the data of 1995. In fact, the infiltrated water in 1996 remobilized the salts trapped and concentrated in the soil and in the unsaturated zone during the long period of low precipitations.

Table 2. Total variance of factor in the essaouira basin.

\begin{tabular}{ccccc}
\hline & Eigenval & $\begin{array}{c}\text { \% Total } \\
\text { Variance }\end{array}$ & $\begin{array}{c}\text { Cumul. } \\
\text { Eigenval }\end{array}$ & $\begin{array}{c}\text { Cumul. } \\
\%\end{array}$ \\
\hline 1 & 3.27 & 40.90 & 3.27 & 40.90 \\
2 & 1.49 & 18.69 & 4.77 & 59.59 \\
3 & 1.40 & 17.44 & 6.16 & 77.03 \\
\hline
\end{tabular}

However, dilution effects can be observed in a particular recharge environment. Indeed, spatial distributions of sodium and chloride for 1996 (Figure 5) show that the lowest concentrations are in the NE area immediately southward of Ksob wadi. It highlights the aquifer recharge by Ksob wadi and the dilution originated by it. This recharge was also confirmed via water flow measurements in this wadi [10].

The higher concentrations located in the central part of the area are a result of the influence of the Tidzi diapir in the water recharge, leading to high contents in sodium and chloride, according to the main flow direction. The evolution of these parameters do not indicate the main flow direction probably as related to the Ksob wadi recharge and the dilution effect generated by it.

\subsection{Anthropogenic Influence on the Aquifers Contamination}

In 1995, nitrate concentrations in the groundwater system of Essaouira basin ranged from 1.4 to $187 \mathrm{mg} / \mathrm{L}$ (Table 3). The mean $\mathrm{NO}_{3}^{-}$concentration was $53.5 \mathrm{mg} / \mathrm{L}$ and $45 \%$ of the groundwater samples exceeded $45 \mathrm{mg} / \mathrm{L}$ [2], which is the World Health Organization maximum amount of $\mathrm{NO}_{3}^{-}$content for drinking water.

In 1996 the nitrate content was higher than the one of the previous campaign, the concentration ranged from 1.6 to $295.8 \mathrm{mg} / \mathrm{L}$, with a mean value of $91.5 \mathrm{mg} / \mathrm{L}$ being $65 \%$ of the groundwater samples over $45 \mathrm{mg} / \mathrm{L}$. The $\mathrm{NO}_{3}^{-}$and $\mathrm{Cl}^{-}$concentration increasing after the rains of 1996's supports the above hypothesis for the external origin of these elements as well as the salt remobilization phenomena triggered by precipitation after a long period of drought.

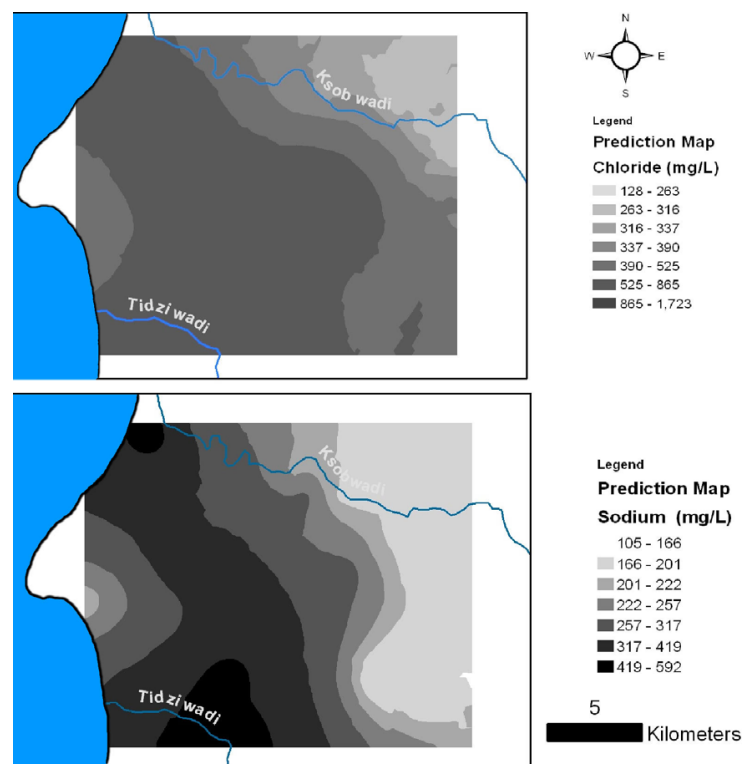

Figure 5. Spatial distribution of sodium and chloride and sodium in the Essaouira basin. 
Table 3. Correlation matrix in the essaouira basin.

\begin{tabular}{cccccccccc}
\hline & $\mathrm{HCO}_{3}^{-}$ & $\mathrm{Cl}^{-}$ & $\mathrm{NO}_{3}^{-}$ & $\mathrm{SO}_{4}^{2-}$ & $\mathrm{Na}^{+}$ & $\mathrm{K}^{+}$ & $\mathrm{Ca}^{2+}$ & $\mathrm{Mg}^{2+}$ \\
\hline $\mathrm{HCO}_{3}^{-}$ & 1.00 & -0.38 & -0.18 & 0.12 & 0.11 & -0.15 & -0.19 & 0.20 \\
$\mathrm{Cl}^{-}$ & -0.38 & 1.00 & 0.52 & -0.06 & 0.77 & 0.08 & 0.79 & 0.65 \\
$\mathrm{NO}_{3}^{-}$ & -0.18 & 0.52 & 1.00 & -0.39 & 0.36 & 0.04 & 0.38 & 0.33 \\
$\mathrm{SO}_{4}^{2-}$ & 0.12 & -0.06 & -0.39 & 1.00 & 0.18 & 0.23 & 0.04 & 0.09 \\
$\mathrm{Na}$ & 0.11 & 0.77 & 0.36 & 0.18 & 1.00 & 0.26 & 0.46 & 0.59 \\
$\mathrm{~K}$ & -0.15 & 0.08 & 0.04 & 0.23 & 0.26 & 1.00 & -0.06 & -0.30 \\
$\mathrm{Ca}$ & -0.19 & 0.79 & 0.38 & 0.04 & 0.46 & -0.06 & 1.00 & 0.66 \\
$\mathrm{Mg}$ & 0.20 & 0.65 & 0.33 & 0.09 & 0.59 & -0.30 & 0.66 & 1.00 \\
\hline
\end{tabular}

The nitrate distribution also indicates the oued contribution in the groundwater mineralization, by dilution the groundwater near this river assume lower concentrations in this pollutant (Figure 6).

Based on the different nitrate content at the Essaouira, one might think that important amount of fertilisers were used in intensive agricultural activities in Morocco. The main source of nitrate is associated to wrong wells design, lack of head well protection (e.g. hand-dug wells with no casing and cover), lack of head well protection areas, traditional extraction methods, accumulation of livestock waste nearby the wells. The lack of prevention and environmental programs for the population seriously threatens the groundwater resources and leads to poor quality in the water supplies.

In relation to the sulphates, the origin in the both aquifers could be similar. In Essaouira sulphates are probably the result of evaporites and diapiric dissolution, but they could also be the result of the fertilisers. However, we haven't obtained any correlation between sulphates and other element that supports the different origins (Table 4).

\subsection{Geochemical Modelation}

In the Essouaira basin, in spite of the occurrence of calcareous and dolomitic levels, all waters are of Na-Cl-type. The chemical signature of these waters should be the result of the preferential recharge area that is located in the Tidzi diapir. A high correlation coefficient was found between electrical conductivity, chlorides and sodium contents, suggesting the large contribution of these elements to the groundwater chemical load. Nevertheless, occulted by chloride the groundwater is highly bicarbonate as a result of the presence of carbonate compounds in the reservoirs matrix.

Analysing the dispersion of the values of the parameters is probable that the difference between the maximum values and the average is a result of a punctual increase. However, the present range is in majority a result of the oued contribution into groundwater recharge, leading to a dilution of the water mineralization. Another hypothesis

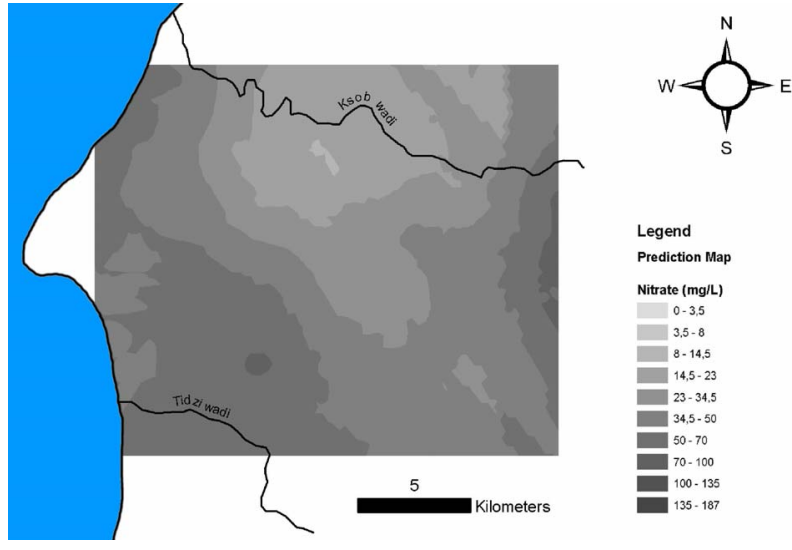

Figure 6. Spatial distribution of nitrate in the Essaouira basin.

to explain the range in mineralization could be the available time in the water rock interaction with the diapir that constitutes the basin.

If we assume that sample 23 is representative of the water, it is expected that waters progressively increase the concentrations of chemical constituents. The higher $\mathrm{Na}$ and $\mathrm{Cl}$ concentration could be explained by the calcite and halite dissolution. Calculated saturation index (S.I.) indicated that the majority of groundwaters are near equilibrium with respect to calcite and strongly undersaturated relatively with halite. The progressively increasing EC values, $\mathrm{Cl}$ and $\mathrm{Na}$ concentrations due to increased water rock interaction would ultimately result in higher saturation indexes values with respect to the referred minerals.

Using a simple mass balance model through the PHREEQC program this scenario was tested. The reaction path was assumed to be such that waters observed at shallow depths evolved to more mineralised waters. We considered a path that initiated in sample 23 that was calculated on the basis of the behaviour of groundwater mineralisation with different percentages of halite dissolution (Table 3).

Figure 7 shows the results of modelling, with halite dissolution at open system where are projected all the 
Table 4. Physical parameters and chemical analyzes of water from the aquifer.

\begin{tabular}{|c|c|c|c|c|c|c|c|c|c|c|}
\hline Point d'eau & $\mathrm{T}\left({ }^{\circ} \mathrm{C}\right)$ & $\begin{array}{c}\text { C.E. } 25^{\circ} \mathrm{C} \\
(\mu \mathrm{s} / \mathrm{cm})\end{array}$ & $\begin{array}{l}\mathrm{HCO}_{3}^{-} \\
(\mathrm{mg} / \mathrm{l})\end{array}$ & $\begin{array}{c}\mathrm{Cl}^{-} \\
(\mathrm{mg} / \mathrm{l})\end{array}$ & $\begin{array}{c}\mathrm{NO}_{3}^{-} \\
(\mathrm{mg} / \mathrm{l})\end{array}$ & $\begin{array}{c}\mathrm{SO}_{4}^{2-} \\
(\mathrm{mg} / \mathrm{l})\end{array}$ & $\begin{array}{c}\mathrm{Ca}^{2+} \\
(\mathrm{mg} / \mathrm{l})\end{array}$ & $\begin{array}{l}\mathrm{Mg}^{2+} \\
(\mathrm{mg} / \mathrm{l})\end{array}$ & $\begin{array}{l}\mathrm{Na}^{+} \\
(\mathrm{mg} / \mathrm{l})\end{array}$ & $\begin{array}{c}\mathrm{K}^{+} \\
(\mathrm{mg} / \mathrm{l})\end{array}$ \\
\hline $140 / 51$ & 19 & 2700 & 363.6 & 738.4 & 42.5 & 177.8 & 179.6 & 56.6 & 333.5 & 3.1 \\
\hline $11 / 51$ & 18 & 4830 & 263.5 & 1654.3 & 133.4 & 290.7 & 172.4 & 101.0 & 736.0 & 35.1 \\
\hline $20 / 51$ & 22 & 3250 & 209.8 & 1029.5 & 106.3 & 221.2 & 159.2 & 76.3 & 471.5 & 7.0 \\
\hline M20 & 23 & 3130 & 383.1 & 972.7 & 22.5 & 163.9 & 164.0 & 61.9 & 414.0 & 9.8 \\
\hline $28 / 51$ & 23 & 3360 & 339.2 & 1136.0 & 70.6 & 137.5 & 227.2 & 109.4 & 333.5 & 3.5 \\
\hline $125 / 51$ & 24 & 3330 & 226.9 & 1228.3 & 58.5 & 106.4 & 279.6 & 63.1 & 368.0 & 3.1 \\
\hline $135 / 51$ & 22 & 2500 & 219.6 & 788.0 & 62.0 & 164.8 & 155.2 & 73.7 & 287.5 & 2.3 \\
\hline $116 / 51$ & 22 & 2610 & 285.5 & 671.0 & 165.5 & 143.5 & 194.4 & 69.1 & 299.0 & 1.9 \\
\hline $104 / 51$ & 22 & 2100 & 268.4 & 546.7 & 1.6 & 168.3 & 152.0 & 53.3 & 287.5 & 3.5 \\
\hline $33 / 51$ & 21 & 2340 & 285.5 & 646.1 & 115.2 & 84.3 & 172.0 & 43.2 & 299.0 & 2.3 \\
\hline $261 / 51$ & 23 & 2000 & 266.0 & 436.7 & 79.6 & 178.4 & 146.8 & 48.7 & 241.5 & 2.3 \\
\hline $327 / 51$ & 21.5 & 1870 & 162.3 & 422.5 & 273.2 & 78.6 & 92.0 & 27.8 & 253.0 & 5.1 \\
\hline $149 / 51$ & 22 & 3580 & 353.8 & 1075.7 & & 216.3 & 104.8 & 101.3 & 655.5 & 4.7 \\
\hline $272 / 51$ & 20.5 & 2280 & 295.2 & 600.0 & & 243.3 & 108.0 & 98.4 & 253 & 2.7 \\
\hline M5 & 22 & 1590 & 205.0 & 429.6 & & 100.1 & 112.8 & 55.2 & 200.1 & 12.1 \\
\hline $3 / 51$ & 19 & 2550 & 412.4 & 646.1 & & 163.4 & 117.2 & 52.6 & 391.0 & 4.7 \\
\hline M10 & 19 & 2700 & 390.4 & 777.5 & & 131.8 & 184.4 & 19.4 & 402.5 & 4.7 \\
\hline $133 / 51$ & 22 & 4710 & 307.4 & 1462.6 & & 402.2 & 295.2 & 150.0 & 678.5 & 3.5 \\
\hline $18 / 51$ & 21 & 5040 & 302.6 & 1693.4 & & 418.3 & 320.8 & 76.8 & 713.0 & 3.1 \\
\hline $132 / 51$ & 15.5 & 2580 & 226.9 & 830.7 & & 163.4 & 185.6 & 75.1 & 322.0 & 2.3 \\
\hline $137 / 51$ & 21 & 3490 & 175.7 & 1320.6 & & 129.3 & 248.0 & 91.2 & 471.5 & 3.9 \\
\hline 138/51 & 21 & 3960 & 192.8 & 1487.5 & & 166.4 & 298.4 & 104.6 & 517.5 & 3.9 \\
\hline $21 / 51$ & 20 & 4460 & 207.4 & 1728.9 & & 162.0 & 376.0 & 61.4 & 586.5 & 2.3 \\
\hline $124 / 51$ & 23 & 1860 & 241.6 & 586.8 & & 45.5 & 140.4 & 67.9 & 218.5 & 2.0 \\
\hline $126 / 51$ & 24.5 & 3240 & 222.0 & 1189.3 & & 132.0 & 306.0 & 64.1 & 356.5 & 3.1 \\
\hline $127 / 51$ & 19 & 3570 & 180.6 & 1359.7 & & 131.5 & 325.6 & 106.3 & 391.0 & 2.7 \\
\hline M31 & 23 & 3220 & 102.5 & 1221.2 & & 147.9 & 291.2 & 121.7 & 368.0 & 2.7 \\
\hline M33 & 20.5 & 1890 & 346.5 & 436.7 & & 187.1 & 107.2 & 73.0 & 167.9 & 1.2 \\
\hline $130 / 51$ & 22 & 2170 & 324.5 & 500.6 & & 205.9 & 112.0 & 77.3 & 299.0 & 1.2 \\
\hline $49 / 51$ & 20.5 & 2340 & 369.7 & 532.5 & & 244.6 & 102.0 & 104.4 & 287.5 & 1.6 \\
\hline $93 / 51$ & 21.5 & 2150 & 339.2 & 489.9 & & 202.9 & 111.2 & 128.6 & 230.0 & 1.6 \\
\hline $103 / 51$ & 21 & 2100 & 314.8 & 532.5 & & 213.3 & 112.2 & 85.2 & 207.0 & 2.7 \\
\hline $260 / 51$ & 20.5 & 2090 & 287.9 & 539.6 & & 238.9 & 109.6 & 71.3 & 218.5 & 2.3 \\
\hline $227 / 51$ & 20.5 & 2280 & 295.2 & 600.0 & & 243.3 & 108.0 & 98.4 & 253.0 & 2.7 \\
\hline $27 / 51$ & 21 & 2000 & 358.7 & 433.1 & & 229.4 & 108.0 & 106.1 & 165.6 & 2.3 \\
\hline $236 / 51$ & 21 & 2380 & 342.8 & 582.2 & & 241.4 & 120.0 & 118.1 & 264.5 & 2.0 \\
\hline
\end{tabular}



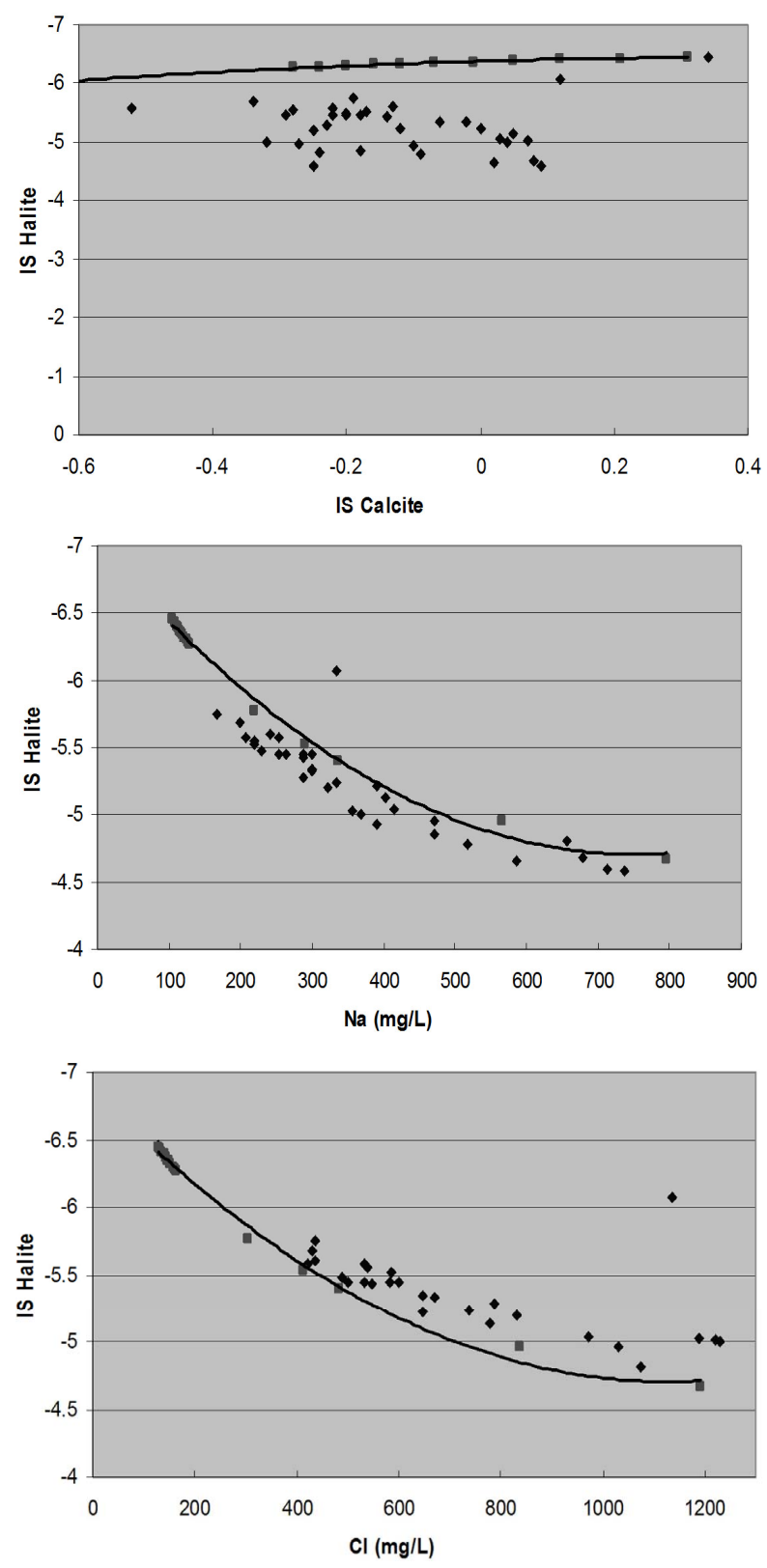

Figure 7. Halite saturation index versus calcite saturation index; sodium and chloride contents.

analysed samples in order to evaluate the behaviour of groundwater from the aquifer. It is possible to notice that the waters are projected along the line that represent the waters evolution in open system, indicated these waters have an important contribution of water-rock interaction in groundwater mineralisation. Corroborating that the chemical signature of these waters should be the result of the preferential recharge area that is located in the Tidzi diaper.

\section{Conclusions}

The economic and social activities in the Essaouira basin depend heavily on groundwater. In this basin, the very high evaporation and scarce precipitation of the semi-arid climate activate the processes of salinization and contamination. In this context, the rainfall triggers a remobilization of residual chemical species and contaminants (sodium, chloride, nitrate) trapped and concentrated in the soil or seeped into the unsaturated zone during the long period of drought. This clearly shows the small potential of natural attenuation by precipitation of the semi-arid regions.

According to the climatic and environmental conditions and social and economical factors it is evident that each of the referred basins requires specific management measures to protect and to preserve the groundwater resources and to guarantee the water supplies. [11] suggest three recommendations that might be useful in the Essaouira basin, where less management measures exist:

The use of the water from Ksob wadi for artificial recharge of the aquifers. In fact, the most significant outflows of the wadi are related to occasional floods in winter. A small part feeds the aquifers and the rest is lost to the Atlantic Ocean.

Improvement of the techniques of drilling, constructing and protecting wells.

Public awareness and participation in water management.

\section{REFERENCES}

[1] M. Bahir, M. Jalal, A. Mennani and A. Fekri, "Contribution à l'Étude Hydrogéologique et Hydrochimique de la Zone Synclinale d'Essaouira (Contribution to the Study of the Hydrogeology Ande Hydrochemistry of the Essaouira Synclinal Area)," Congrès International sur l'Eau et la Désertification, Le Caire, 1999.

[2] M. Bahir, M. Jalal and A. Mennani, "Pollution Nitratée des Eaux Souterraines du Bassin Synclinal d'Essaouira (Groundwater Pollution by Nitrates of the Essaouira Synclinal Basin)," Journal of Environmental Hydrology, Electronic Journal of the International Association for Environmental Hydrology, Vol. 9, No. 18, 2001.

[3] M. Bahir, A. Mennani, M. Jalal and N. Youbi, "Contribution to the Hydric Resources Study of the Essaouira Synclinal Basin (Morocco)," Estudios Geologicos, Vol. 56, No. 3-4, 2000.

[4] F. Duffaud, L. Brun and B. Planchot, "Bassin du SudOuest Marocain (SW Morocco Basin)," In: Reyre, Ed., Bassin Sédimentaire du Littoral Africain, Vol. 9, 1966, p. 18.

[5] Y. Fakir, "Contribution to the Coastal Aquifers StudySahel de Qualidia Case," Ph.D. Thesis, 2001, p. 160.

[6] A. Mennani, V. Blavoux, M. Bahir, Y. Bellion, M. Jalal and M. Daniel, "Chemistry and Isotopes in the Plio-Quaternary and Turoniene Aquifers Funcioning Knowledge in Essaouira Area (Occidental Morocco)," Journal of African Earth Sciences, Vol. 32, No. 4, 2001, pp. 819-835. 
doi:10.1016/S0899-5362(02)00057-X

[7] A. Agoumi, "Introduction à la Problématique des Changements Climatiques (Introduction to the Climate Changes Problem)," Projet Magrébin sur les Changements Climatiques RAB/94/G31, Somigraf, 1999.

[8] A. J. Melloul, "Use of Principal Components Analysis for Studying Deep Aquifers with Scarce Data-Aplication to the Nubian Sandstone Aquifer, Egypt and Israel," Hydrogeologu Journal, Vol. 3, No. 2, 1995, pp. 19-39. doi: $10.1007 / \mathrm{s} 100400050056$
[9] A. Mackiewick and W. Ratajcak, "Principal Components Analysis (PCA)," Computers \& Geosciences, Vol. 19, No. 3, 1993, pp. 303-342. doi:10.1016/0098-3004(93)90090-R

[10] A. Fekri, "Contribution to the Hydric Resources Study of the Essaouira Synclinal Basin (Morocco)," 3rd Cycle, 1993, p. 173.

[11] R. Rajagopal and T. Graham, "Expert Opinion and Groundwater Quality Protection. The Case of Nitrate in Drinking Water," Groundwater, Vol. 27, No. 6, 1989, pp. 835-847. 